\title{
Depression storage and infiltration effects on overland flow depth-velocity-friction at desert conditions: field plot results and model
}

\author{
M. J. Rossi and J. O. Ares \\ National Patagonic Centre, CONICET, Boulvd. Brown 2915, 9120 Puerto Madryn, Chubut, Argentina \\ Correspondence to: M. J. Rossi (rossijulieta@gmail.com)
}

Received: 3 April 2012 - Published in Hydrol. Earth Syst. Sci. Discuss.: 7 May 2012

Revised: 6 August 2012 - Accepted: 20 August 2012 - Published: 14 September 2012

\begin{abstract}
Water infiltration and overland flow are relevant in considering water partition among plant life forms, the sustainability of vegetation and the design of sustainable hydrological models and management. In arid and semi-arid regions, these processes present characteristic trends imposed by the prevailing physical conditions of the upper soil as evolved under water-limited climate. A set of plot-scale field experiments at the semi-arid Patagonian Monte (Argentina) were performed in order to estimate the effect of depression storage areas and infiltration rates on depths, velocities and friction of overland flows. The micro-relief of undisturbed field plots was characterized at $z$-scale $1 \mathrm{~mm}$ through close-range stereo-photogrammetry and geo-statistical tools. The overland flow areas produced by controlled water inflows were video-recorded and the flow velocities were measured with image processing software. Antecedent and postinflow moisture were measured, and texture, bulk density and physical properties of the upper soil were estimated based on soil core analyses. Field data were used to calibrate a physically-based, mass balanced, time explicit model of infiltration and overland flows. Modelling results reproduced the time series of observed flow areas, velocities and infiltration depths. Estimates of hydrodynamic parameters of overland flow (Reynolds-Froude numbers) are informed. To our knowledge, the study here presented is novel in combining several aspects that previous studies do not address simultaneously: (1) overland flow and infiltration parameters were obtained in undisturbed field conditions; (2) field measurements of overland flow movement were coupled to a detailed analysis of soil microtopography at $1 \mathrm{~mm}$ depth scale; (3) the effect of depression storage areas in infiltration rates and
\end{abstract}

depth-velocity friction of overland flows is addressed. Relevance of the results to other similar desert areas is justified by the accompanying biogeography analysis of similarity of the environment where this study was performed with other desert areas of the world.

\section{Introduction}

The complexity of interactions between overland flow and infiltration has long received attention in hydrological studies. The spatial variability of soil microtopography has been identified as a major determinant of infiltration rates and the hydrological response of watersheds (Abrahams et al., 1990; Köhne et al., 2009; Darboux et al., 2001). Usual procedures to study run-off-infiltration processes involve the use of hydrological models based on hydrograph records. Although a large body of literature has been devoted to the criteria used to inspect hydrograph records (Ewen, 2011), less attention has been paid to the fact that many hydrological models that can accurately reproduce hydrograph records, produce severely biased estimates of overland flow velocities (Mügler et al., 2011; Legout et al., 2012) or Reynolds-Froude numbers (Tatard et al., 2008).

Infiltration-run-off models need to calculate the overland flow velocity and depth to be able to simulate the flow of water over the land surface. Frictional effects must be accounted for, usually through simplifying equations of the fundamental hydrodynamic laws on continuity and momentum balance involved. To this aim, most field and laboratory studies on overland flow use the Darcy-Weisbach's $f$ and Manning's $n$ 
(Darboux et al., 2001; Hessel et al., 2003; Li, 2009). Both of these are calculated from the same variables (flow rate, terrain slope, roughness, Reynolds numbers) and both suffer from limitations imposed by the high variability of the represented effects both in space and time. Abrahams et al. (1990) studied Darcy-Weisbach's $f$ for desert hill slopes and found that it varies with the rate of flow. Since the rate of flow is highly variable in space, so too is $f$. Analogous limitations can be expected in relation to Manning's $n$.

In the case of arid and semi-arid areas, complex interactions between run-off generation, transmission and reinfiltration over short temporal scales (Li et al., 2011; Reaney, 2008) add difficulties in the estimation of infiltrationoverland flows. In these areas, the soil surface is predominantly flat and gently sloped at extended spatial scales, and the excess rainfall moves at the surface of the soil in very shallow structures combining small overland flow areas interspersed with finely ramified fingering patterns of small channels. Infiltration in arid and semi-arid regions can also be modified by the development of water-repellent areas (Lipsius and Mooney, 2006) which in cases occur in relation to soil microtopography (Biemelt et al., 2005).

Composite patterns of overland flow (Parsons and Wainwright, 2006; Smith et al., 2011) can be expected to produce spatially heterogeneous patterns of water infiltration in the upper soil (van Schaik, 2009). Results obtained by Esteves et al. (2000) in laboratory run-off plots, indicate that despite the soil being represented by only one set of parameters, infiltration was not homogeneous all over the plot surfaces. They concluded that the microtopography had a strong effect on observed flow directions, producing small ponds along the paths of flow and altering the flow depths and velocity fields.

Descroix et al. (2007) observed that catchments and small plot studies in arid regions usually show a so-called "hortonian" trend, with characteristic absence of base flow. This was the case in semi-arid northern Mexico for catchments as large as tens of thousands of $\mathrm{km}^{2}$, and for approximately $500 \mathrm{~km}^{2}$ in the Western Sierra Madre. Latron and Gallart (2007) working at the Pyrenees determined that there is a strong relationship between the base flow and the extension of saturated areas at the basin scale. In Australia's semi-arid rangelands, patches of bare soils were determined to be the main run-off controlling factor (Cammeraat, 2002; Bartley et al., 2006).

Thompson et al. (2011) observed that the lateral redistribution of ponded water generated during intense rainstorms plays an important role in the hydrological, biogeochemical and ecological functioning of patchy arid ecosystems. Lateral redistribution of surface water in patchy arid ecosystems has been hypothesized to contribute to the maintenance of vegetation patches through the provision of a water subsidy from bare sites to vegetated sites (Bromley et al., 1997). A strong control on field-scale infiltration is exerted by the horizontal spatial variability of infiltration properties (Lipsius and Mooney, 2006; van Schaik, 2009). Such infiltration-overland flow processes occur during hortonian run-off events on sloping ground. Surface flow redistribution may also occur on flat ground if the presence of vegetation patches creates contrasts in infiltration rate between dry soil and water saturated areas. Changes in the pattern of surface water re-distribution occur during early stages of desertification (Ares et al., 2003). Several studies indicate that the horizontal movements of the naturally scarce rainfall water on the surface soil in arid regimes contribute to define the spatial pattern of woody and herbaceous vegetation forms as well as the extent of bare soil patches (Aguiar and Sala, 1999; Ares et al., 2003; Borgogno et al., 2009; Dunkerley, 2002).

Water infiltration in the soil has been successfully modelled through various techniques. Some existing models apply numerical solutions to the Richards equation (Radcliffe and Simunek, 2010; Weill et al., 2011), while others use various modifications to the Green-Ampt (Green and Ampt, 1911) model (Gowdish and Muñoz Cárpena, 2009; Mengistu et al., 2012; Schröder, 2000).

Experiments and models on overland flow have extensively used so-called kinematic wave reduced solutions to the Saint-Venant (S-V) equations (Mügler et al., 2011; Thompson et al., 2011). The numerical solutions of these reductions require the estimation of frictional effects acting on overland flow. Also, in order to construct continuity equations, the average depth of the overland flow must be known as well as its propagation velocity. Although the $\mathrm{S}-\mathrm{V}$ equations have consistently proved capable of accurately simulating hydrographs at plot scale, most of the assumptions underlying the estimation of frictional forces and flow depth do not hold when applied to overland flows in field conditions (Smith et al., 2007). Moreover, the choice of roughness models to be used in the $\mathrm{S}-\mathrm{V}$ equations is most often done with the purpose of increasing the hydrograph quality, while the actual travel time of water is ignored. In extended hydrological practice, frictional factors are usually taken from published tables or assumed spatially constant (Esteves et al., 2000).

Plot experimentation has long been relevant in developing physically based models of water flow (Köhne et al., 2009). The term usually refers to laboratory (Antoine et al., 2011; Dunkerley, 2001, 2002; Legout et al., 2012) or field (Esteves et al., 2000; Mengitsu et al., 2012) studies involving areas in the scale of some few square meters, where water inflow conditions can be manipulated with varying success. Plot studies on overland flows sometimes use natural rainfall falling on the plot as water input (Esteves et al., 2000) or a controlled water inflow either through rain simulation over the whole plot surface (Abrahams et al., 1990; Biemelt et al., 2005; Mügler et al., 2011), or through drippers, perforated pipes, etc. at the top of the plots (Dunkerley, 2001, 2003; Hessel et al., 2003). In these latter cases, a reduced area within the plot receives the water input, while overland flow is observed at the rest of the area. This is considered adequate since during storm events, surface routing, stem flows, etc. may result in water inflows relatively un-related to the instantaneous 
rainfall input as a consequence of the position of the plot area in the drainage network. Abrahams et al. (1990) used trickles to supply $140000 \mathrm{~mm}^{3} \mathrm{~s}^{-1}$ to the top of $10 \mathrm{~m}^{2}$ plots in studies of flow resistance in semi-arid environments, while Dunkerley (2003) choose perforated pipes to deliver $1 \times 10^{3}$ to $9 \times 10^{3} \mathrm{~mm}^{3} \mathrm{~s}^{-1}$ to laboratory plots of $1.4 \mathrm{~m}^{2}$.

Plot studies usually require some disturbance of naturally occurring conditions, like constructing flumes (Esteves et al., 2000; Giménez et al., 2004), modifying the soil surface to obtain desired flow channels (Mügler et al., 2011) or simulating the soil surface with technical artifacts (Dunkerley, 2003). Rainfall-run-off plot experiments where a device is used to generate rainfall events mimicking natural conditions may also require measuring the water flow at an outlet in order to compute water mass balances (Grierson and Oades, 1977; Cerdá et al., 1997). These experimental setups introduce artifacts affecting to some degree the characteristics of the overland flows as compared to those under field conditions.

Plot experiments are often used to obtain estimates of depression storage (DS) (Antoine et al., 2011) in studies of overland flow, in the context of interpreting DS retention effect on hydrograph records (Govers et al., 2000; Hansen, 2000; Darboux et al., 2001). The underlying concept is that DS areas behave as a temporary passive storage of overland flow resulting in a delay in the hydrograph signals. This in turn prompts interest in its direct measurement at the plot scale through geometrical analysis of elevation models (Planchon and Darboux, 2002) or from surface roughness measurements (Antoine et al., 2011).

Comparisons among results obtained in field studies on overland flows at various semi-arid/arid environments might benefit from biogeography analysis of the corresponding experimental sites. Regional similarities as estimated through comparative biogeography (Parenti and Ebach, 2009) result from analyzing spatial and functional patterns of biodiversity, species distribution, and geological history.

This study is part of a larger project at the National Patagonic Centre (Chubut, Argentina) to develop tools for the eco-hydrological analysis of the desertification processes. It builds on previous results obtained by Ares et al. (2003) indicating that early desertification processes involve modifications of the overland flow patterns and its distribution among the various vegetation life forms in the Patagonian Monte (Argentina). Here, an experimental protocol is presented of the field plot experiments and coupled simulation model to estimate infiltration and overland flow parameters in the Monte environment. The protocol involves parameters that can be quantitatively estimated with an adequate degree of precision (overland flow velocity, infiltration depth, soil water content, depression storage area) as well as others that can indirectly be estimated through modelling results (surface frictional effect, average overland flow depth, ReynoldsFroude numbers). Specifically, this study addresses: (1) the effect of plot microtopography on infiltration-overland flows, and (2) the estimation of overland flow parameters (velocity, depth, friction) needed to characterize water movement at the soil surface. A biogeography analysis of the similarity of the experimental site in this study with other areas of the world is also included to ease eventual comparisons of the results presented here with those obtained in similar studies.

\section{Site and field experiments}

\subsection{Biogeography of the experimental site}

The Monte desert is a South American subtropical to warm temperate desert and semi-desert located in western $\mathrm{Ar}$ gentina from $24^{\circ} 15^{\prime} \mathrm{S}$ to $44^{\circ} 20^{\prime} \mathrm{S}$. The study here presented was performed at a representative site of the biome in the area of the Patagonian Monte, a temperate region with a Mediterranean-like rainfall regime produced by the Westerlies from the Pacific affected by the rain shadow effect from the Andes (Abraham et al., 2009). Past precipitation records, observed (Haylock et al., 2006) and predicted precipitation anomalies expected under various scenarios of climate change (Carrera et al., 2007), indicate that precipitation events may occur at both high $\left(>20 \mathrm{~mm} \mathrm{day}^{-1}\right)$ as well as low $\left(<3 \mathrm{~mm} \mathrm{day}^{-1}\right)$ depths. This pattern corresponds to alternative atmospheric mechanisms of rain generation characteristic of the tropical regime prevailing at the northern part of the territory or prevailing winter-rain of the temperate latitudes (Prohaska, 1976). Both types are observable at times along most of the area occupied by the biome. There is a remarkable convergence between the desert areas of North and South America (Monte, Chihuahuan-Sonoran deserts) consisting in the same climate subtypes, the same dominant vegetation and the same combination of biological forms (Morello, 1984 as quoted by Abraham et al., loc. cit.). Similar conditions are extensively found in arid and semi-arid climates worldwide (Mares et al., 1985).

This study was carried out at the wildlife refuge "La Esperanza", (southern portion of the Monte desert) which occupies an area of about $42000 \mathrm{~km}^{2}$ in southeastern Argentina (León et al., 1998; Soriano, 1950). The mean annual temperature is $13.4^{\circ} \mathrm{C}$ and the mean annual precipitation is $235.9 \mathrm{~mm}$ (1982-2001). The characteristics of the site as representative of the Monte desert are based on the analysis of the dominant vegetation life forms. The local vegetation covers about $40 \%$ and $60 \%$ of the soil in a random patchy structure with three vegetation layers: the upper layer (1-2 m height) dominated by tall shrubs (Larrea divaricata, Schinus johnstonii Barkley, Chuquiraga erinacea Don., Atriplex lampa Gill. ex Moq., and Lycium chilense Miers ex Bert.), the intermediate layer (0.5-1.2 m height) also composed by dwarf shrubs (Nassauvia fuegiana (Speg.) Cabrera, Junellia seriphioides (Gillies and Hook) Mold., and Acantholippia seriphioides (A. Gray) Mold.), and the low layer (0.1-0.5 m height) dominated by perennial grasses (Nassella tenuis (Phil.) Barkworth, Pappostipa speciosa (Trin. and Rupr.) Romasch, and 
Poa ligularis (Nees ex Steud)) (Ares et al., 1990; Carrera et al., 2008). Soils are a complex of Typic Petrocalcids-Typic Haplocalcids with a fractured calcium carbonate layer from 0.45 to $1 \mathrm{~m}$ below the soil surface (del Valle, 1998). Upper soil texture types (USDA) are sandy or loamy sand.

\subsection{Field experiments}

Ten field plot experiments in undisturbed bare soil patches $(800 \times 800 \mathrm{~mm})$ along a $540 \mathrm{~m}$, down-sloping $(-7.2 \%)$ transect from S: $-42.17046, \mathrm{~W}:-64.96343$ to S: -42.21366 , W: -64.99225 were conducted during the dry season on days with air temperatures in the range of $20-32{ }^{\circ} \mathrm{C}$. The spatial arrangement of plots was aimed to explore an altitudinal range of variation of soil texture. Water inflow to plots was applied at mid/low-slope length locations of inter-mound soil areas through a portable, wind protected, single-nozzle system mounted at $30 \mathrm{~cm}$ above soil level on a wooden frame, and calibrated with a pressure gauge to supply water inflow rates in the range $225-4500 \mathrm{~mm}^{3} \mathrm{~s}^{-1}$ to a small area $(4.7 \pm 5.2 \%)$ of each plot that was further neglected for estimations of overland flow velocities. This created two plot sub-regions: one directly receiving the water inflow and another receiving the overland flow resulting from the excess of water input to the former. The water inflow range was aimed to simulate flow accumulation values at the spatial scales of this study as estimated with a flow routing algorithm (Tarboton and Ames, 2001). The frame supported a Kodak EasyShare Z712 IS 7.1 MP camera $\left({ }^{\circledR}\right.$ Eastman Kodak Company, Rochester, New York) with video mode, at near zenith position over the centre of the plot and about $1 \mathrm{~m}$ above ground level to obtain images of the whole plot area. Video records of the expanding overland wetted areas were obtained during experiments of varying time length (72-1128 s) until the wet front reached some of the borders of the camera image in any direction. This implied a zerodischarge condition (all overland flow was infiltrated within the observed plot areas at the end of the experiments).

Soil moisture was evaluated immediately after the water inflow ceased with a TDR (Time-Domain Reflect meter, TRIME $^{\circledR}{ }_{-}$FM, Ettlingen) pin $(50 \mathrm{~mm})$ probe inserted at a proper angle in order to sample the top $30 \mathrm{~mm}$ of the soil at equidistant (30-35 mm) points of a grid covering the whole overland flow area and neighbouring dry points. TDR estimates of soil moisture were calibrated with gravimetric estimates $\left(y=1.166 x+0.05 ; R^{2}=0.92, n=101 ; x\right.$ : gravimetric $\theta$ estimate) obtained by extracting $2-5$ soil cores (Ø: $40 \mathrm{~mm}$ ) along the main axis of the overland flow plumes, at the centre of the directly wetted area and equidistant positions up to the wetted border and control at nearby dry soil (Fig. 1). Soil cores were extended to depths $0-30,30-90$ and 90 $180 \mathrm{~mm}$, brought to the laboratory in sealed containers and wet-dry $\left(105^{\circ} \mathrm{C}\right)$ weighed for moisture content. Gravimetric moisture was expressed in volumetric terms through correction with soil bulk density measured through the excavation

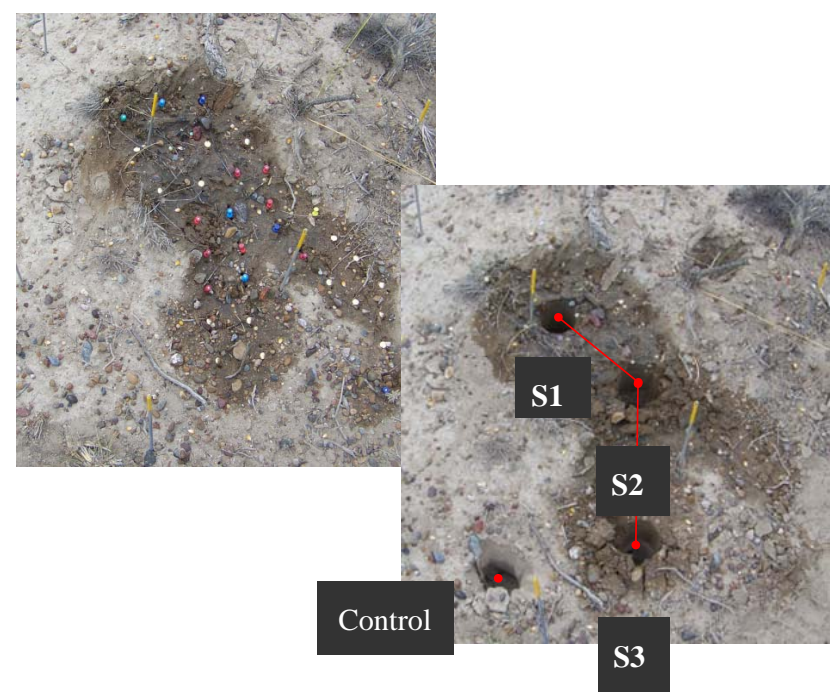

Fig. 1. Left panel: overhead view of a field plot in this study at the end of the water inflow period with TDR probe position marks and spikes with control marks used in the CRS-GSM procedure. Right panel: soil cores along the main axis of the overland flow area are already extracted. Flow occurred in the direction S1 to S3.

method (ISO 11272, 1998) at a nearby location. Maps of soil moisture in the wetted area at the end of the water inflow period were based on calibrated TDR estimates. Map values were obtained by interpolation of 4-6 closest TDR estimates, based on a search radius algorithm (Idrisi v. 14.02, Clark Labs, Worcester).

The texture of the extracted soil core samples was measured with Lamotte's 1067 texture kit (LaMotte Co., Chestertown) calibrated with replicate estimates obtained at two reference laboratories (National Patagonic Centre, National University of the South, Argentina) with the Robinson's protocol (Gee and Bauder, 1986). Parameters corresponding to residual volumetric moisture $\left(\theta_{\mathrm{r}}\right)$, saturated moisture content $\left(\theta_{\mathrm{s}}\right)$, saturated hydraulic conductivity $\left(K_{\text {sat }}\right)$ tortuosityconnectivity (L), and shape of the soil moisture-water head function $\left(\log _{10} \alpha, \log _{10} n\right)$ (Van Genuchten, 1980) corresponding to the obtained soil samples were estimated based on textural data through an ANN (Artificial Neural Net) pedotransfer algorithm (Rosetta v. 1.2, US Salinity Laboratory, Riverside) developed by Schaap and Leij (1998).

A methodology (Rossi and Ares, 2012) combining CloseRange Stereophotogrammetry (CRS) and Geo-Statistical Modelling (GSM) was applied to obtain Digital Elevation Models (DEM) (resolution $8.23 \pm 0.24 \mathrm{~mm}, P<0.05$, $n=10$ ). The coordinates of 9 control points and a minimum of 64 targets obtained through CRS were loaded to an application (I-Witness v. 1.4, DCS Inc., Bellevue, WA, USA) for orthorectification and further processed with a kriging algorithm (Surfer v. 7, Golden Software Inc., Colorado) to obtain plot DEMs and DEM-based flow vector fields. Digital videoimages of the overland flowing water plume were selected 
at regularly spaced time intervals (6-240 s). The spacing of time intervals within this range was selected according to the duration of the experiments. Time intervals were constant $(\mathrm{Ti}=6 \mathrm{~s})$ for those experiments of short duration with relatively higher water input rates (Plots 1 to 4 ). In longer experiments with low water input rates (Plots 5 to 10), time intervals $(s)$ were selected according to $\mathrm{Ti}=\left(e^{(0.265 \times t s)}\right) \times 6$, where $t s$ is the cardinal number of the interval. This resulted in 10-18 images at short intervals during the early stages of fast overland flow and gradually longer intervals during later stages of slow overland flow. Images were then exported to an image processing application (Idrisi v. 14.02, Clark Labs, Worcester), ortho-rectified (RMSE: $7.59 \pm 1.3 \mathrm{~mm}$, $P<0.05, n=10)$ and overlaid to their corresponding plot DEM and map of flow vector fields at the same resolution of the DEM. Flow vectors were estimated from the DEM. At any map node, flows were in the direction of the steepest descent and the magnitude of the arrow depended on the steepness of the descent. The terrain height change corresponding to the overland flow advance at each time interval was evaluated by averaging the altitude differences between all pixels along the borders of successive images.

Depression storage (DS) (Antoine et al., 2011) areas were identified at each sampling interval $\left(t_{n+1}, t_{n}\right)$ by measuring the area $A(t)_{n+1}-A(t)_{n}$ advanced by the overland plumes during the $n$-th interval, discriminating between: (1) area advanced down slope, and (2) area advanced in a counterslope direction (CSA, Counter-Slope-Advance). CSA estimates were then weighed to correct for great advances at flow start and small advances at flow end:

$w(t)=\frac{A(t)_{(n+1)}-A(t)_{(n)}}{A(t)_{(n+1)}}$,

and DS was expressed as the accumulated CSA areas as a percent of $A(t)_{n+1}$ (also see Fig. 2):

$\operatorname{DS}(t) \%=\frac{\left(\sum_{t=1}^{t=n} \operatorname{CSA}(t)_{(n+1)} \times w(t)\right) \times 100}{A(t)_{(n+1)}}$.

\section{Model}

The changes observed at the overland flow areas and subsurface soil water content at the plots were modelled with a physically based continuity model consisting of a set of non-linear ordinary differential and continuity equations with time variable parameters representing the changes in storages of overland water (Eq. 3) and at the upper vadose zone (Eq. 4):

$$
\frac{\mathrm{d} Q_{\mathrm{o}}}{\mathrm{d} t}=W-\mathrm{IN}(t)-O(t)
$$

$\frac{\mathrm{d} Q_{\mathrm{v}}}{\mathrm{d} t}=\mathrm{IN}(t)$

$\mathrm{CW}=Q_{\mathrm{o}}+Q_{\mathrm{v}}$.

$Q_{\mathrm{o}}$ : Water stored at the overland plume $\left(\mathrm{mm}^{3}\right)$.

$Q_{\mathrm{v}}$ : Water stored at the upper vadose zone $\left(\mathrm{mm}^{3}\right)$.

$W$ : Water inflow $\left(\mathrm{mm}^{3} \mathrm{~s}^{-1}\right)$.

$\mathrm{IN}(t)$ : Total infiltration flow $\left(\mathrm{mm}^{3} \mathrm{~s}^{-1}\right)$.

$\mathrm{CW}$ : Cumulative water inflow $\left(\mathrm{mm}^{3}\right)$.

$O(t)$ : overland flow $\left(\mathrm{mm}^{3} \mathrm{~s}^{-1}\right)$.

Note that evaporation was disregarded due to the short duration of the field experiments. While $W$ is time constant for each single plot experiment, $\mathrm{IN}_{\mathrm{t}}-O_{\mathrm{t}}$ can be expected to change with time depending on the effects of soil microrelief and the physical properties of the surface soil. Further, the overland flow plume includes DS areas where water accumulates during the water inflow period, and other parts where the water inflow is not enough to maintain free water at the soil surface. Accordingly, IN( $t$ ) may be expected to result from the composition of flows under both saturated and unsaturated conditions. Saturated conditions occur at DS areas, while both saturated and/or unsaturated infiltration flows can occur at other areas depending on their water content:

$\mathrm{IN}(t)=\operatorname{IN}_{\mathrm{sat}}(t)+\operatorname{IN}_{\text {unsat }}(t)$.

$\operatorname{IN}_{\mathrm{sat}}(t)$ : transient, saturated infiltration flow at DS areas $\left(\mathrm{mm}^{3} \mathrm{~s}^{-1}\right)$.

$\operatorname{IN}_{\text {unsat }}(t)$ : transient, saturated and/or non-saturated infiltration flow at non-DS areas $\left(\mathrm{mm}^{3} \mathrm{~s}^{-1}\right)$.

The $\mathrm{IN}_{\mathrm{sat}}$ flow was modelled through a Darcy's law concept, where infiltration was assumed to occur under saturated conditions depending on the gradient of water head between the soil surface and a point at the infiltrating wetting front (see Appendix A):

$\mathrm{IN}_{\mathrm{sat}}=K_{\mathrm{sat}} \times\left[\psi_{\mathrm{f}} \times\left(\frac{\theta_{\mathrm{s}}-\theta(t)}{F}\right)+1\right] \times A_{\mathrm{DS}}$

$F=z_{\mathrm{f}}(t) \times\left(\theta_{\mathrm{s}}-\theta(t)\right)$.

$K_{\text {sat }}$ : saturated hydraulic conductivity $\left(\mathrm{mm} \mathrm{s}^{-1}\right)$.

$\psi_{\mathrm{f}}(\theta)$ : suction at the wetting front $(\mathrm{mm})$.

$\theta_{\mathrm{s}}, \theta(t)$ : saturation and instantaneous volumetric water content at the wetting front respectively (dimensionless).

$F$ : accumulated infiltration $(\mathrm{mm})$.

$A_{\mathrm{DS}}$ : DS area $\left(\mathrm{mm}^{2}\right)$.

$z_{\mathrm{f}}(t)$ : instantaneous water infiltration depth $(\mathrm{mm})$.

In areas of the overland plume where no DS occurs, water infiltration was assumed to occur under unsaturated conditions (see Appendix A). Replacing in Eqs. (7) and (8) through corresponding terms:

$\begin{aligned} \operatorname{IN}_{\text {unsat }}(t) & =K_{\mathrm{h}}(\theta(t)) \times\left[\psi_{\mathrm{f}}(\theta(t)) \times\left(\frac{\theta(t)-\theta_{i}}{F}\right)+1\right] \\ & \times\left(A(t)-A_{\mathrm{DS}}\right) .\end{aligned}$ 
a

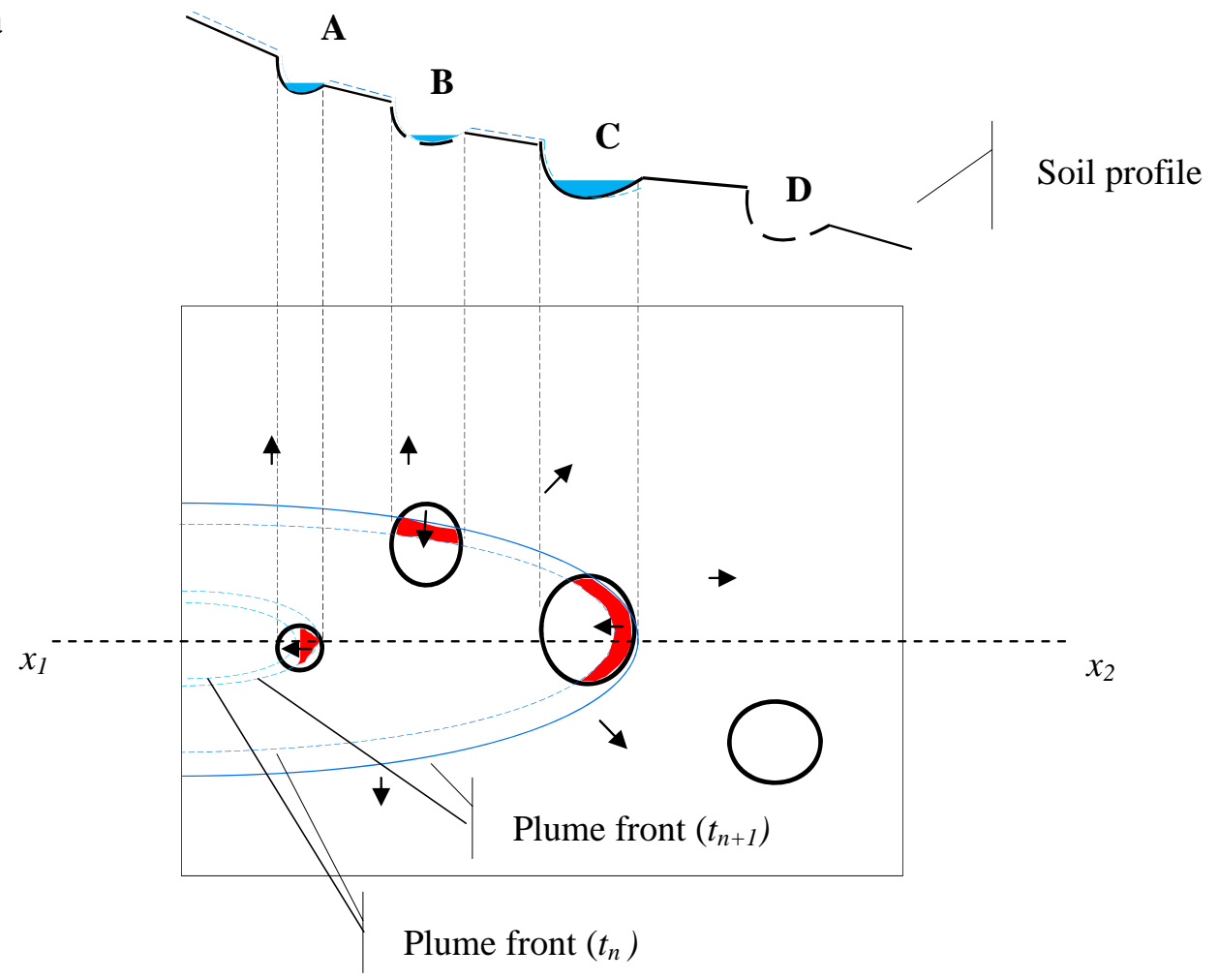

b

$t_{n}: 6 \mathrm{~s} ; t_{n+1}: 16 \mathrm{~s}$

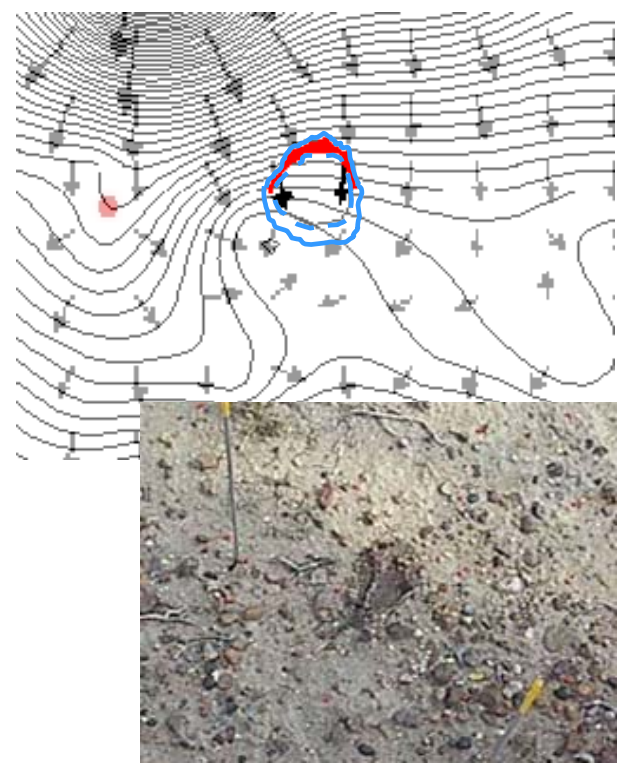

$t_{n}: 340 \mathrm{~s} ; t_{n+1}: 450 \mathrm{~s}$

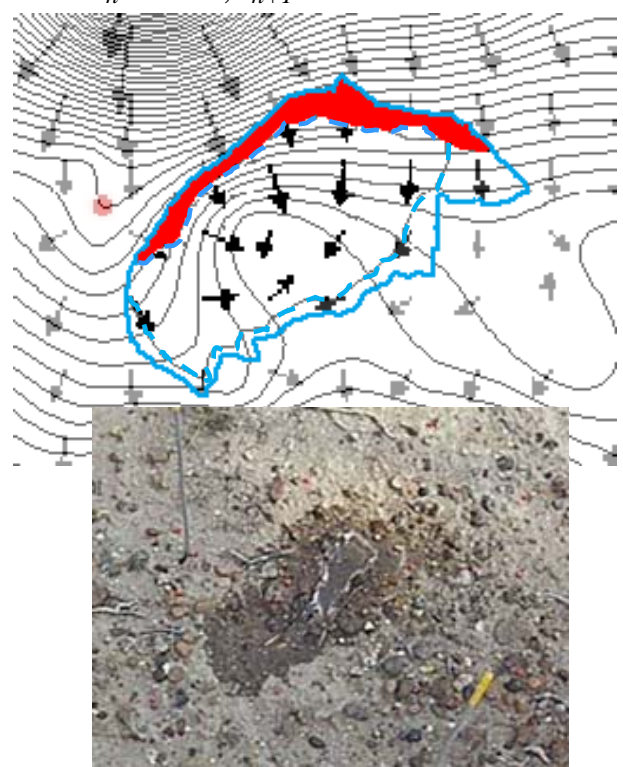

CSA areas

Fig. 2. Estimation of local CSA (Counter-Slope-Advance) overland plume areas in this study. (a) An example of a soil profile at $x_{1}-x_{2}$ with micro-depressions (A-D). An overland plume advances down-slope from left to right up to depression $C$, over totally ponded A-C and partially ponded B. Plume fronts circumscribe plume areas $A(t)(n)$ and $A(t)(n+1)$ (see Eqs. 1-2). Part (red areas) of the plume advances occur up-slope while the plumes fill depressions and finally overflow the depression boundaries. (b) Scene examples (lower insets) of plume advances at Plot $\# 10$ at two sampling intervals. Left panel: $t_{n}: 6 \mathrm{~s}, t_{n+1}: 16 \mathrm{~s}$; right panel: $t_{n}: 340 \mathrm{~s}, t_{n+1}: 450 \mathrm{~s}$ after water inflow start, overlaid on the plot DEM (contour interval: $1 \mathrm{~mm}$ ) with DEM-based flow arrows. 
Table 1. Calibration parameters and variables of soil surface and upper vadose and convergence criteria used in tuning a model of the field plot experiments. ANN CI: Confidence interval of the ANN estimation process; $r$ : correlation coefficient, linear regression model-data values $\left(x_{\text {model }}=a+b \times x_{\text {data }} ; H_{0}: a=0, b=1\right)$ over all plot experiments. $(A(t))$ : convergence evaluated at $10-15$ times during the water inflow period (**: statistical significance at $P<0.05$ ).

\begin{tabular}{llll}
\hline & Parameter & Convergence criteria & Compartment \\
\hline 1 & Sand $(\%)$ & Data value & Soil \\
2 & Silt $(\%)$ & Data value & Soil \\
3 & Clay $(\%)$ & Data value & Soil \\
4 & $\theta_{\text {sat }}$ & Data value & Soil \\
5 & $\theta_{\mathrm{r}}$ & Data value & Soil \\
6 & $\theta_{\text {antecedent }}$ & Data value & Soil \\
7 & Water inflow $W\left(\mathrm{~mm}^{3} \mathrm{~s}^{-1}\right)$ & Data value & Surf. soil \\
8 & Water inflow period $(\mathrm{s})$ & Data value & Surf. soil \\
9 & $K_{\mathrm{S}}\left(\mathrm{mm} \mathrm{s}^{-1}\right)$ & ANN CI $-r^{* *}$ & Soil \\
10 & Wet Area $(A(t))\left(\mathrm{mm}^{2}\right)$ & EC $\geq 0.99^{*}$ & Surf. soil \\
11 & Total Wet Area $\left(A^{*}\right)\left(\mathrm{mm}^{2}\right)$ & $r^{* *}$ & Surf. soil \\
12 & Average run-off velocity $\left(\mathrm{mm} \mathrm{s}^{-1}\right)$ & $r^{* *}$ & Surf. soil \\
13 & Average $S(\mathrm{~mm})$ & $r^{* *}$ & Surf. soil \\
14 & Average DS area $(\%)$ & $r^{* *}$ & Surf. soil \\
15 & $\theta_{\text {end }}$ & $r^{* *}$ & Soil \\
16 & End $z_{\mathrm{f}}(\mathrm{mm})$ & $r^{* *}$ & Soil \\
17 & Water mass balance error $\left(\mathrm{mm}^{3}\right)$ & $e<1 \times 10^{-6} \mathrm{~mm}^{3}$ & Soil \\
\hline
\end{tabular}

* Nash and Sutfliffe (1970).

$K_{\mathrm{h}}(\theta(t))$ : variable hydraulic conductivity $\left(\mathrm{mm} \mathrm{s}^{-1}\right)$.

$\theta_{i}$ : Antecedent water content of the soil.

$A(t)$ : Wet area of overland plume at time $t\left(\mathrm{~mm}^{2}\right)$.

$K_{\mathrm{h}}(\theta(t))$ and $\psi_{\mathrm{f}}(\theta(t))$ were estimated through the solution (van Genuchten, 1980) of Mualem's (Mualem, 1976) formulation to predict the relative hydraulic conductivity from knowledge of the soil-water retention curve.

The instantaneous overland water volume was estimated as

$Q_{\mathrm{o}}=A(t) \times \mathrm{d}(t)$.

$\mathrm{d}(t)$ : average depth of the overland flowing water volume at time $t$ (mm).

Flowing in the $x-y$ space, with varying velocity depending on the local altitude gradient along its border, such that $\mathrm{d}(t)$ is inversely related to the slope of the underlying soil surface. This relation would follow Darcy's general form of frictional law (Dingman, 2007; Mügler et al., 2011):

$\mathrm{d}(t)=\left(\frac{W}{C}\right)^{2} / S(t, t+\mathrm{d} t)$.

$C$ : Proportionality constant.

$S(t, t+\mathrm{d} t)$ : Average terrain height drop around the overland plume during the interval $t, t+\mathrm{d} t(\mathrm{~mm})$.

Where the velocity term is replaced in this case with the water inflow rate $W$, and $S(t, t-\mathrm{d} t)$ was obtained from successive video images of the overland flow overlaid on the plot DEMs. The term $C$ was found through inverse modelling of the continuity Eqs. (3)-(5), solved through numerical integration with a fourth-order Runge-Kutta approximation, at solution time intervals $0.06 \leq \Delta t \leq 0.3 \mathrm{~s}$, and an accepted mass balance error threshold $e \leq 1 \times 10^{-6} \mathrm{~mm}^{3}$.

\section{Modelling parameters and variables: calibration and validation}

Table 1 summarizes the parameters and variables used to calibrate the model of the field plot experiments. Model calibration was achieved through trial-error on parameter $C$ and simultaneous calibration on parameters 9-16 (Table 1). In order to restrict the possibility of compensatory artifacts during the calibration process, the quality of the calibration procedure was evaluated through simultaneous convergence of all measured values describing the experimental setting, the morphology of the plot surface soil and the texturalhydrological properties of the upper vadose zone. The criteria in the case of parameters $1-8$ was strict convergence to measured data values. Convergence of parameter $9\left(K_{\mathrm{S}}\right)$ was pursued within the confidence interval of the ANN estimation process as reported in Shaap and Leij (1998). Variable $10(A(t))$ was required to converge to time-serial data as estimated through a Nash-Sutcliffe's efficiency coefficient (EC $\geq 0.99)$ (Nash and Sutcliffe, 1970). Values of 11-16 were required to converge to:

$\Sigma_{i=1, n}\left(x_{i}-x_{\text {data }}\right)^{2}=\min$

where $x_{i}$ is the model estimate and $x_{\text {data }}$ is the corresponding experimental-measured value. 11-16 were further tested 
for convergence to data at the inter-plot scale such that their correlation with measured values would be significant at $P<0.01$ over the set of 10 plots studied. Variables $12-14$ are average values of the corresponding variable over the simulation time.

Several procedures were used for model validation. Unit consistency and ranges of $K_{\mathrm{S}}, K_{\mathrm{h}}(\theta(t))$, and $\psi_{\mathrm{f}}(\theta(t))$ were independently checked through comparison with estimates obtained with CHEMFLO-2000 (Nofziger and Wu, 2003), an application that solves Richards equations in one-dimension to simulate transient water (and chemical) transport in soils.

In order to detect eventual spurious correlation values (Table 2 , column " $r$ ") resulting from outlier data points, confidence intervals $(P<0.05)$ of the correlation coefficient $r$ of measured-modelled values 9-16 were built by bootstrapping randomly selected paired 5-plot sets. $z_{\mathrm{f}}$ and $\theta_{\text {end }}$ values observed in the field were additionally tested for consistency with CHEMFLO-2000 estimates.

Additionally, the following variables were defined based on model outputs:

$\varsigma^{*}=\left(\Sigma_{t=1, n}(O(t) / W(t)) / n\right.$.

$\varsigma^{*}$ : mean run-off coefficient

where $\varsigma^{*}$ is a mean (dimensionless) run-off estimate, of $\varsigma=O(t) / W(t)$, including transient depression storage.

$d^{*}=\left(\Sigma_{t=1, n} \mathrm{~d}(t)\right) / n$.

$d^{*}:$ mean $\mathrm{d}(t)(\mathrm{mm})$

$v^{*}=\left(A^{*}\right)^{0.5} / t_{\text {end }}$.

$v^{*}$ : mean overland flow velocity $\left(\mathrm{mm} \mathrm{s}^{-1}\right)$.

Several parameters of the experimental plots which are usually estimated in overland flow studies (Abrahams et al., 1990; Parsons et al., 1994; Dunkerley, 2001) were also computed to ease comparisons of conditions in this study with reported data. As long as basic assumptions underlying their rationale are granted, the Froude number $(F)$ relates the velocity of the overland laminar flow to the expected velocity of a gravitational wave, or the ratio of the laminar flow inertia to gravitational forces. Analogously, the dimensionless Reynolds number $(R e)$ gives a measure of the ratio of inertial forces to viscous forces for given flow conditions. High Reynolds numbers characterize turbulent flow.

\section{Results}

Table 2 summarizes results obtained from the plot experiments and the calibration of their models. The upper vadose zone $\left(z_{\mathrm{f}} \leq 55 \mathrm{~mm}\right)$ of all plots showed various combinations of sand, silt and clay fractions within the boundaries of Sandy-Loam and Loamy-Sand USDA textural classes (Parameters 1-3) as well as their basic hydraulic properties (parameters $4-5,9)$. The values of parameter 6 corresponded to

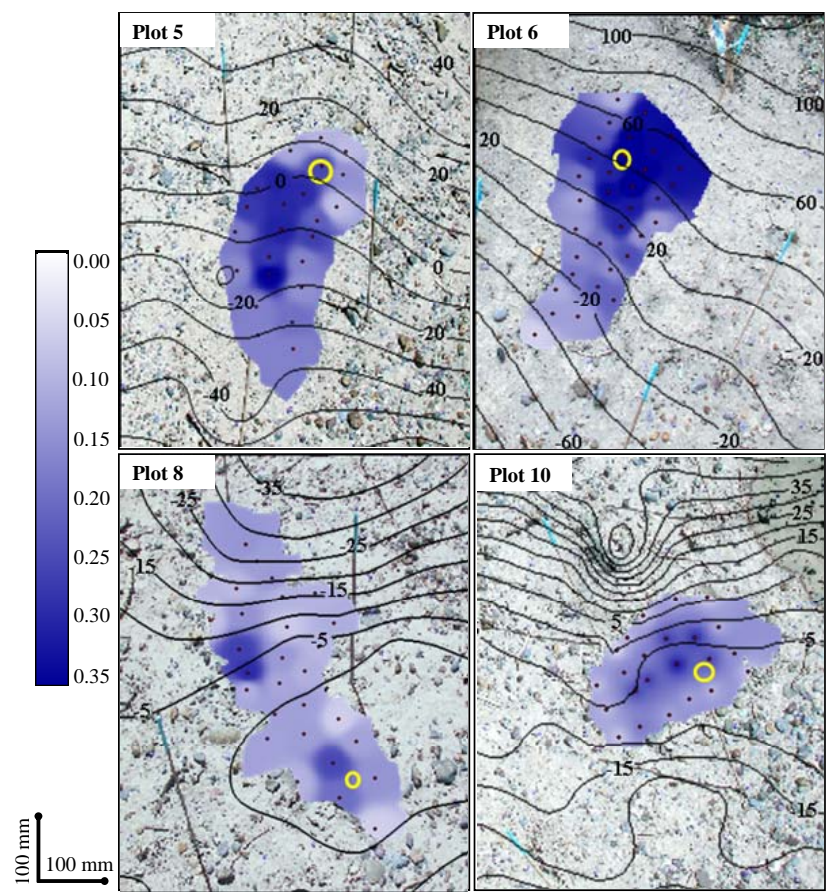

Fig. 3. Upper soil moisture $\left(\theta_{\text {end }}, 0-30 \mathrm{~mm}\right)$ maps of the overland plumes based on TDR probing (black dots) at the end of the water inflow periods at four plots in this study. Yellow circles indicate the water inflow areas. Maps overlay rectified plot photos and corresponding level ( $\mathrm{mm})$ contour lines.

very dry conditions of the upper soil due to the fact that all the plot experiments were performed during the dry season of the local climate regime. The range of water input flows (parameter 7) produced groups of relatively fast and slow overland flow and water infiltration conditions. Calibration values of $K_{\text {sat }}$ and parameters 11-16 were significantly correlated with data values. $H_{0}: a=0, b=1$ was rejected in the case of parameter $16\left(z_{\mathrm{f}, \text { model }}=-8.41+0.955 \times z_{\mathrm{f}, \text { data }}, P=1.42 \mathrm{E}-06\right)$. This is to be expected due to the fact that $z_{\text {f,data }}$ were estimated from soil cores along the main overland flow axes, while $z_{\text {f,model }}$ expresses the average infiltration depth corresponding to the whole wet area. The modeled time series of overland flow areas $A(t)$ (variable 10) were in all cases significantly correlated with the observed areas as indicated by the Nash-Sutcliffe's EC.

Figure 3 shows examples of maps of the distribution of upper vadose zone $(0-30 \mathrm{~mm})$ moisture $\left(\theta_{\text {end, } 0-30 \mathrm{~mm}}\right)$ at four plots in this study as obtained with the TDR probe at the end of the water inflow period. Depending on the position of the water inflow and the local microtopography, some areas contain moisture at near saturation levels while various levels of unsaturated conditions prevailed at other areas.

Figure 4 shows comparisons of $z_{\mathrm{f}}$ and $\theta_{\text {end }}$ values as obtained from the CHEMFLO-2000 simulation with estimates from the model in Sect. 3; photographs of soil cores at the water inflow areas are also shown for comparison. Figure 5 


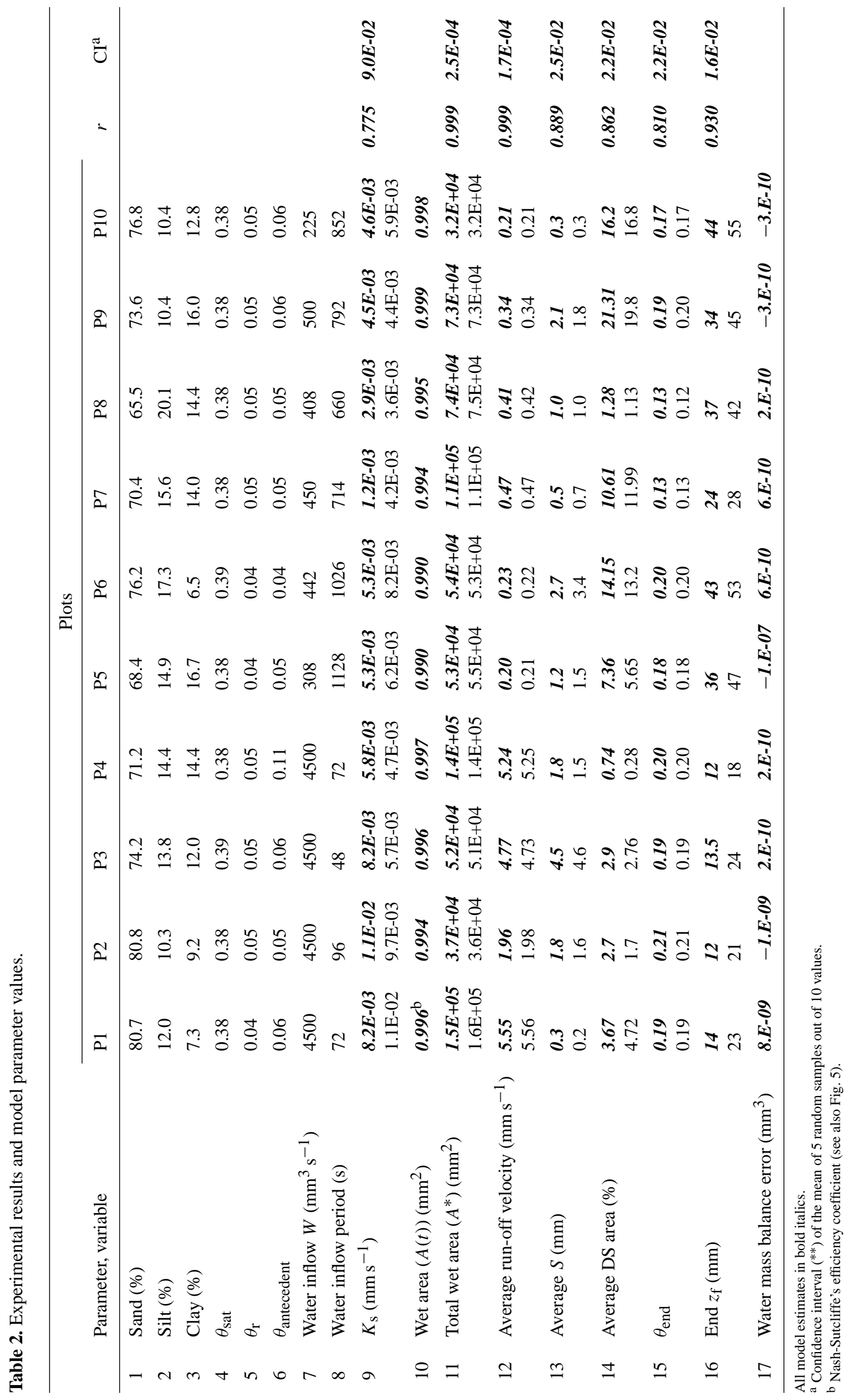


Table 3. Froude $(F)$, Reynolds $(R e)$ numbers and $C, d^{*}$ parameter values and slopes $(s, \%)$ of the field plot experiments.

\begin{tabular}{llllllllllll}
\hline & & $\mathrm{P} 1$ & $\mathrm{P} 2$ & $\mathrm{P} 3$ & $\mathrm{P} 4$ & $\mathrm{P} 5$ & $\mathrm{P} 6$ & $\mathrm{P} 7$ & $\mathrm{P} 8$ & $\mathrm{P} 9$ & $\mathrm{P} 10$ \\
\hline 1 & $F^{\mathrm{a}}$ & 0.096 & 0.006 & 0.033 & 0.051 & 0.005 & 0.001 & 0.012 & 0.008 & 0.005 & 0.005 \\
2 & $R e^{\mathrm{b}}$ & 8.39 & 101.77 & 45.76 & 16.22 & 0.19 & 3.71 & 0.33 & 0.84 & 0.68 \\
3 & $C$ & $9.50 \mathrm{E}+04$ & $4.80 \mathrm{E}+03$ & $7.60 \mathrm{E}+03$ & $1.50 \mathrm{E}+04$ & $3.50 \mathrm{E}+03$ & $8.60 \mathrm{E}+02$ & $7.00 \mathrm{E}+03$ & $4.6 \mathrm{E}+03$ & $3.20 \mathrm{E}+03$ & $5.0 \mathrm{E}+03$ \\
4 & $d^{*}$ & 0.34 & 11.40 & 2.16 & 1.09 & 0.21 & 3.70 & 0.16 & 0.28 & 0.45 & 0.19 \\
5 & $s$ & 1.1 & 14.0 & 2.9 & 7.2 & 7.8 & 1.7 & 2.2 & 5.5 & 11.0 & 3.0 \\
\hline
\end{tabular}

${ }^{\text {a }} F=v^{*} /\left(g \times d^{*}\right)^{0.5} ; g=9806.65 \mathrm{~mm} \mathrm{~s}^{-12}$

b $\operatorname{Re}=4 \times v^{*} \times d^{*} / v ; v=0.9 \mathrm{~mm}^{2} \mathrm{~s}^{-1}$

Plot 3

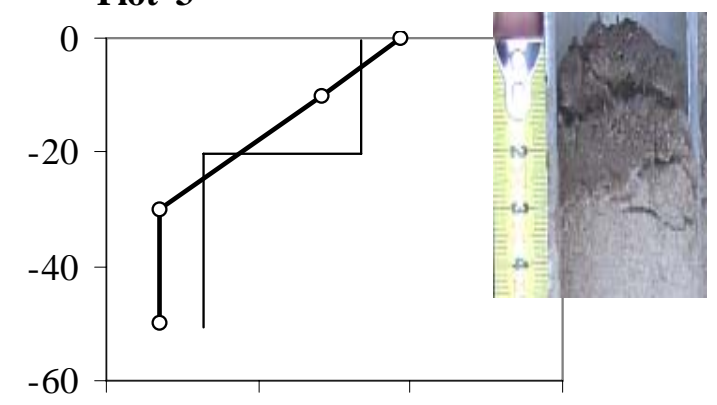

Plot 6

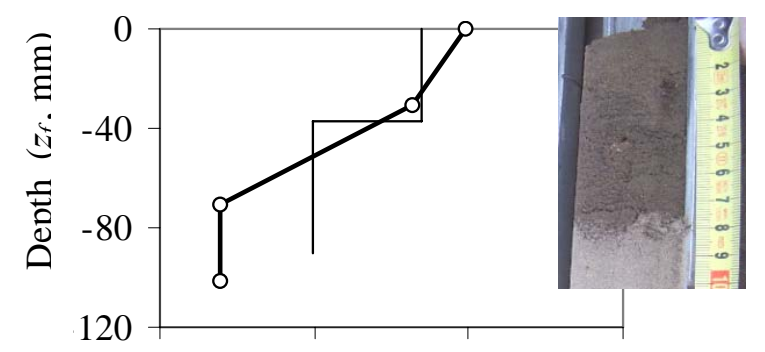

Plot 8

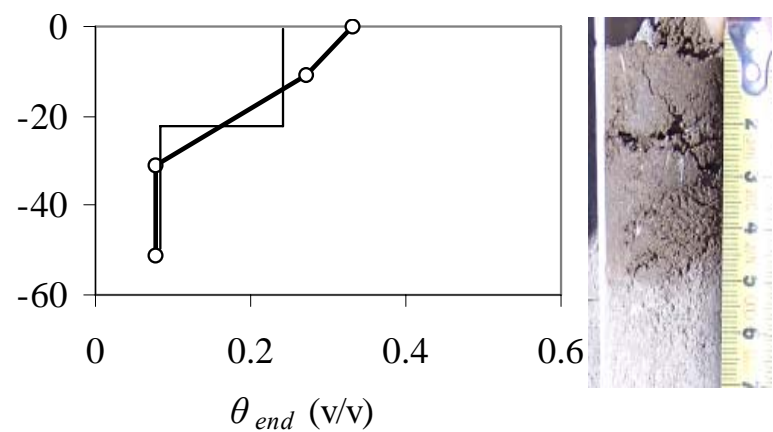

Fig. 4. Comparison of $z_{\mathrm{f}}$ (photo insets) and $\theta_{\text {end }}$ field soil core data (circle-lines) used as an input to the model in this study and estimates through CHEMFLO-2000 (lines). Soil core photos obtained immediately after ceasing water inflow are also shown.
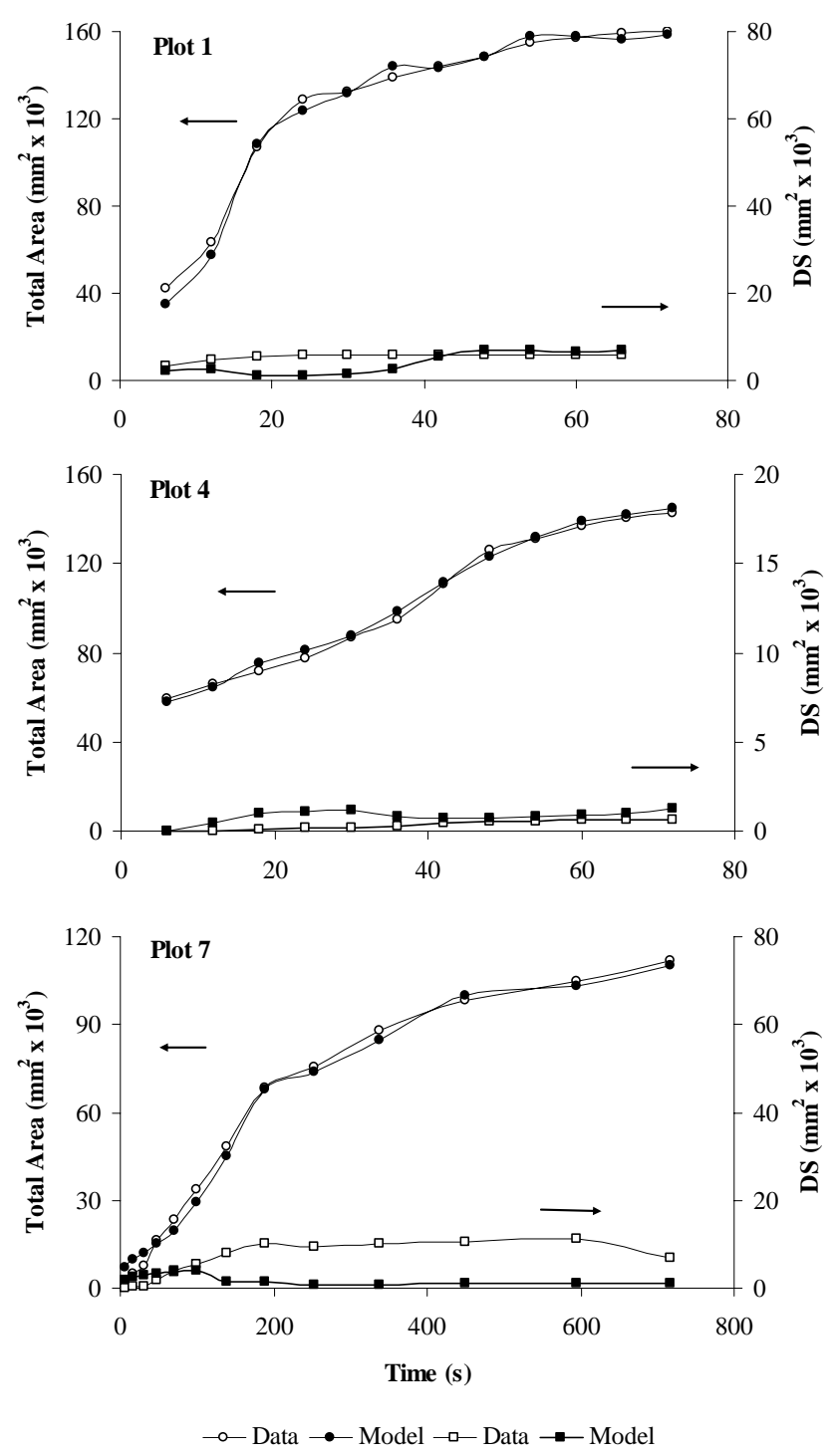

Fig. 5. The progression of overland flow $A(t)$ and DS areas during the water inflow periods in three field plots as estimated from rectified video imagery and the model used in this study. 

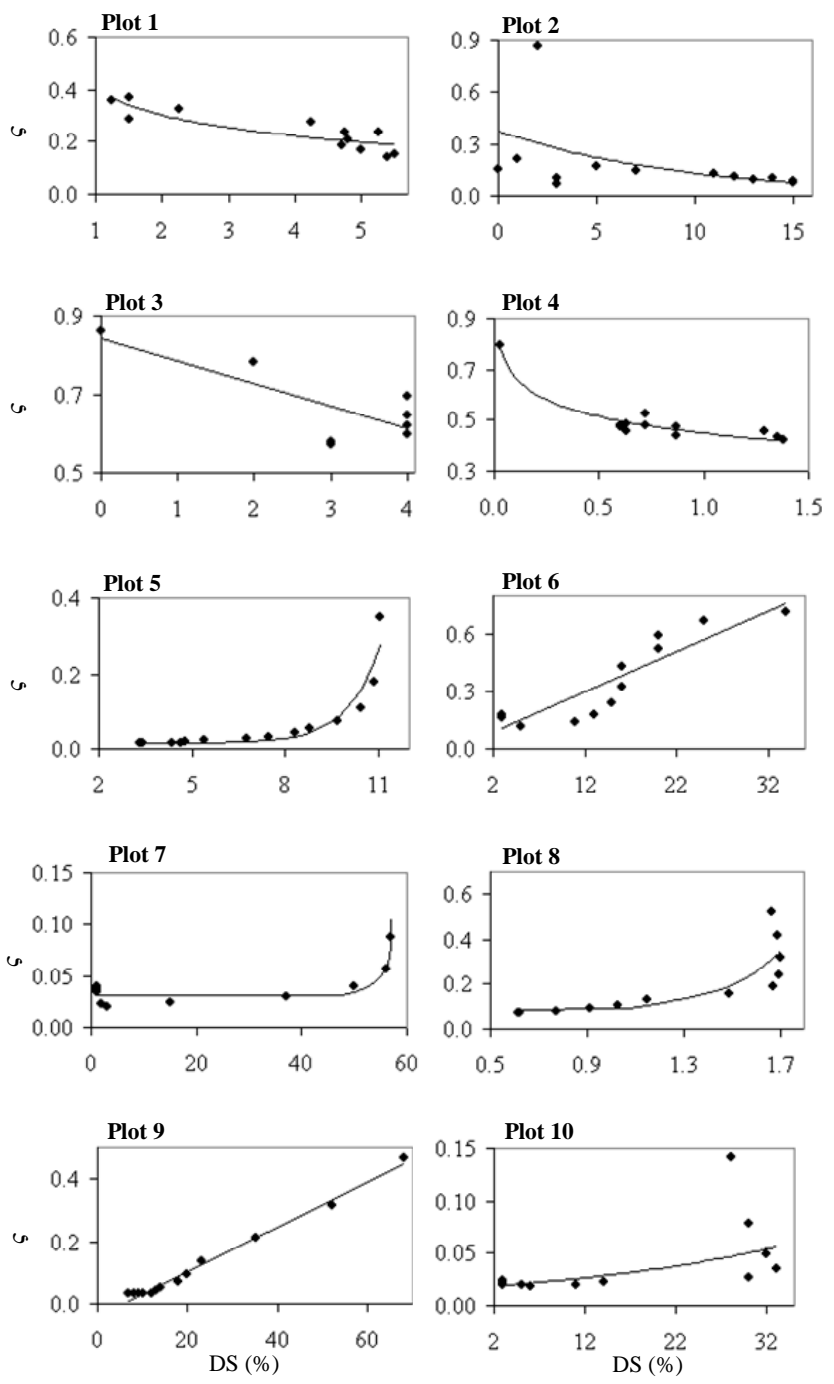

Fig. 6. Intra-plot time-serial relations between the estimated DS and the runoff $(\zeta)$ coefficient.

shows $A(t)$ values and point and average estimates of DS areas of several plots as measured and estimated with the model of Eqs. (3)-(5).

No significant correlations were found between the extent of DS areas and other variables at the inter-plot scale. At intra-plot scale (time-serial values corresponding to sampling time intervals at each experimental plot) run-off $(\varsigma)$ values were variously related to DS (Fig. 6) depending on the water inflow. At plots 1-4 (high inflow rate), decreasing relations were observed. Run-off increased with DS estimates at most plots under low water inflow.

Table 3 summarizes theoretical hydrodynamic overland flow parameters of the plot experiments and Fig. 7 shows the relation $C-F$.

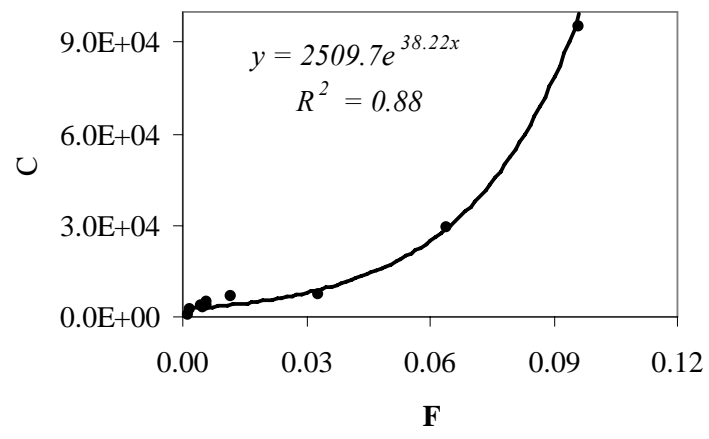

Fig. 7. Inter-plot statistical relations between parameters $C-F$.

\section{Discussion}

In plot experiments where natural or simulated rain occurs over the plot area the kinetic energy of the rainfall may modify the overland flow momentum and velocity. Measured ranges of rainfall kinetic energy all over the world under various methods indicate a range of $12-22 \mathrm{~J} \mathrm{~m}^{-2} \mathrm{~mm}^{-1}$ for a storm of $10 \mathrm{~mm} \mathrm{~h}^{-1}$ (Rosewell, 1986), which is a common event in semi-desert areas under tropical regime. Aside from potential effects on soil microtopography (erosion) these energy inputs can reasonably be expected to contribute to the overland flow momentum balance.

Flume plot experiments (Esteves et al., 2000; Dunkerley, 2004) may introduce various kinds of artifacts. To avoid wall effects, the soil relief must be manipulated in order to deliver the overland flow to the central part of the flume. In laboratory flume experiments, the natural soil must be transported and necessary modifications in soil structure must follow. Overland flow studies using technical materials to simulate the soil surface might not reproduce field conditions.

Experiments on overland flow involving the measurement of run-off through an outlet (a need in computing water mass balances and runoff coefficients) may require modifications of the soil microtopography to deliver run-off to the outlet. Interflow measurement (Wang et al., 2011) might require sophisticated outlet configurations.

Some of the above mentioned potential limitations of plot studies on overland flow were addressed through the experimental setup in this study. Estimates of overland flow depth, velocity and friction were obtained without manipulation of the microtopography of field plots; overland-infiltration flows were considered simultaneously and the effect of depression storage areas was estimated. Inertial forces acting on the overland flows were small as estimated through $F$ numbers (Table 3 ). Flows were predominantly laminar (see Re numbers, Table 3).

The consideration of the soil as a heterogeneous system at physical non-equilibrium (PNE) has been applied to a number of hydrological models (see Köhne et al., 2009 for an extensive review of various forms of published PNE models). In most cases, the emphasis has been focused on the effects 
of sub-surface soil heterogeneity on infiltration flows. In this study, attention is given to surface soil heterogeneity in the $x-y$ plane and it is hypothesized that infiltration must occur under saturated conditions at DS areas, while both saturatedunsaturated infiltration could occur at non-DS areas. This interpretation is consistent with observations on composite overland flow by Abrahams et al. (1990) on run-off plots in arid southern Arizona (USA), where flow occurred as shallow sheets of water with threads of deeper, faster flow diverging and converging around surface protuberances, rocks, and vegetation.

The results presented in Fig. 6 indicate that the effect of DS areas on the overland flow (as estimated through the runoff coefficient) is more complex than expected from considering those as areas of passive transient water storage. The effect of DS areas may result from various transient balances of inflow, overland flow and infiltration. This view is supported by the results of the time serial relations DS- $\varsigma$ which are predominantly increasing at plots with low rates of water inflow and decreasing at plots with high water inflow. In explaining these trends, it should be considered that after the initiation of a water inflow exceeding the infiltration rate (plots 1-4), DS areas become filled before the underlying top soil reaches saturation. This is reflected in shallow end $z_{\mathrm{f}}$ values $(23.7 \pm 3.9 \mathrm{~mm}$, see Table 2 , \#16). The DS effect on overland flow approaches that of a passive storage and results in decreasing DS-run-off relations (Fig. 6). In the cases of plots receiving low inflows during longer periods (Plots P5-P10), the water inflow is nearly balanced by the saturated infiltration at DS areas. In these plots deeper $z_{\mathrm{f}}$ values $(45 \pm 10.1 \mathrm{~mm}$, see Table 2, \#16) were observed. Once the upper soil profile under DS areas becomes saturated, infiltration in DS areas diminishes reaching a low, steady rate (Mao et al., 2008) and the run-off flow increases with increasing DS.

Equations (11) and (14) allow the estimation of the average overland flow depth $d^{*}$ once the term $C$ is estimated through inverse modelling of the continuity Eqs. (3)-(5). The term $C$ is similar to the Chezy frictional constant, in that the flow velocity $(v)$ is replaced by the water inflow rate $(W)$ in Eq. (11). However, $C$ is indeed a friction descriptor as confirmed through its high correlation with the Froude number (Table 3, Fig. 7).

Values $\mathrm{d}(t)-d^{*}$ (Table 3 ) obtained in this study are in a similar scale as those reported by Esteves et al. (2000) and instrumentally measured by Dunkerley (2001) in laboratory conditions and Smith et al. (2011) in field conditions.

\section{Conclusions}

This study gives the following findings about the effects of depression storage and infiltration on overland flow characteristics: (1) overland flow properties (velocity, depth, friction) as well as infiltration-overland flow mass balances are consistently modelled by considering variable infiltration rates corresponding to depression storage and/or non-ponded areas. (2) The effect of DS on run-off varies depending on the local soil balance of water inflow and infiltration, the latter modified by the local microtopography.

A protocol of experiments in undisturbed field conditions and coupled time-distributed modelling to $1-2$ above is described. A biogeography-based analysis of the experimental site is given to ease comparisons with experiments on overland flows in other areas of the world.

\section{Appendix A}

\section{Saturated-unsaturated infiltration}

Consider a soil profile at an experimental plot surface (Fig. A1) receiving a continuous water inflow $(W)$. A water front at the soil surface limits a soil area where simultaneous saturated infiltration occurs at ponded areas, and un-saturated infiltration occurs in non-ponded sectors.

Saturated infiltration can be estimated from Darcy's equation:

$$
\begin{aligned}
q & =K_{\text {sat }} \frac{\mathrm{d} h}{\mathrm{~d} z}=K_{\text {sat }} \frac{h_{2}-h_{1}}{z_{2}-z_{1}}=K_{\text {sat }} \frac{\left(\psi_{\mathrm{f}}+z_{\mathrm{f}}\right)-(d+0)}{z_{\mathrm{f}}-0} \\
& =K_{\text {sat }} \frac{\psi_{\mathrm{f}}+z_{\mathrm{f}}-d}{z_{\mathrm{f}}}
\end{aligned}
$$

where

$q=$ infiltration rate at saturated condition $\left(\mathrm{mm} \mathrm{s}^{-1}\right)$,

$K_{\text {sat }}=$ saturated hydraulic conductivity $\left(\mathrm{mm} \mathrm{s}^{-1}\right)$,

$\psi_{\mathrm{f}}=$ suction at wetting front $(\mathrm{mm})$,

$d=$ the depth of overland flow (mm).

A cumulative depth of infiltration $F(\mathrm{~mm})$ is defined:

$F=z_{\mathrm{f}}\left(\theta_{\mathrm{s}}-\theta_{\mathrm{i}}\right)$,

where

$\theta_{\mathrm{i}}=$ initial volumetric moisture content (dimensionless) and

$\theta_{\mathrm{s}}=$ saturated volumetric moisture content (dimensionless), rearranging Eq. (A2) and substituting into Darcy's equation:

$$
\begin{aligned}
q & =\frac{\mathrm{d} F}{\mathrm{~d} t}=K_{\mathrm{sat}} \frac{\psi_{\mathrm{f}}+\frac{F}{\theta_{\mathrm{s}}-\theta_{\mathrm{i}}-d}}{\frac{F}{\theta_{\mathrm{s}}-\theta_{\mathrm{i}}}} \\
& =K_{\mathrm{sat}}\left(\psi_{\mathrm{f}}+\frac{F}{\theta_{\mathrm{s}}-\theta_{\mathrm{i}}}-d\right) \frac{\theta_{\mathrm{s}}-\theta_{\mathrm{i}}}{F} .
\end{aligned}
$$

Assuming $d$ is small relative to the other terms, the previous equation simplifies to

$\mathrm{IN}_{\mathrm{sat}}=\frac{\mathrm{d} F}{\mathrm{~d} t}=K_{\mathrm{sat}}\left(\psi_{\mathrm{f}} \frac{\theta_{\mathrm{s}}-\theta_{\mathrm{i}}}{F}+1\right)$,

which is the Green and Ampt infiltration rate equation. When the soil is not saturated, the infiltration rate can be calculated as in Eq. (A1) substituting into the Buckingham-Darcy equation: 


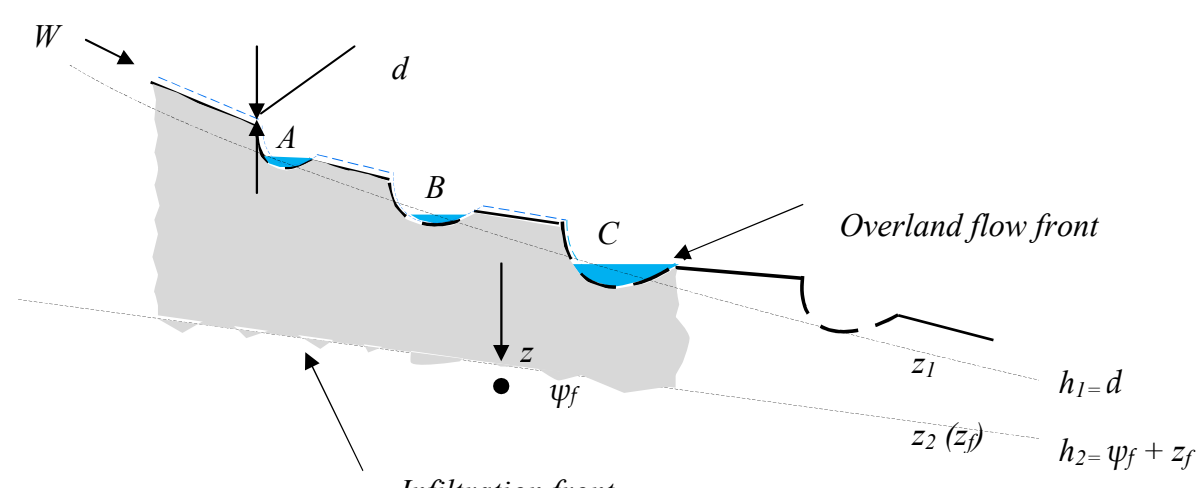

Infiltration front

Fig. A1. Schematic representation of parameters involved in considering infiltration up to depth $z_{\mathrm{f}}$ of a water inflow $W$ on sloping soil with partially ponded depressed areas (A-C) (also see main text, Fig. 2).

$$
\begin{aligned}
q & =K_{\mathrm{h}} \frac{\mathrm{d} h}{\mathrm{~d} z}=K_{\mathrm{h}} \frac{h_{2}-h_{1}}{z_{2}-z_{1}}=K_{\mathrm{h}} \frac{\left(\psi_{\mathrm{f}}+z_{\mathrm{f}}\right)-(d+0)}{z_{\mathrm{f}}-0} \\
& =K_{\mathrm{h}} \frac{\psi_{\mathrm{f}}+z_{\mathrm{f}}-d}{z_{\mathrm{f}}}
\end{aligned}
$$

where $K_{\mathrm{h}}(\theta)$ and $\psi_{\mathrm{f}}(\theta)$ are the variable hydraulic conductivity and the variable suction, respectively.

Substituting in Eq. (A3) and assuming $d$ is small in relation to the other water potential terms:

$\mathrm{IN}_{\text {unsat }}=\frac{\mathrm{d} F}{\mathrm{~d} t}=K_{\mathrm{h}}\left(\psi_{\mathrm{f}} \frac{\theta_{\mathrm{unsat}}-\theta_{\mathrm{i}}}{F}+1\right)$,

where $\theta_{\text {unsat }}$ is the unsaturated water content of the soil.

Acknowledgements. This study was supported by grants of Agencia Nacional de Investigaciones Científicas y Técnicas (ANPCyT) PICT 07-1738 and Consejo Nacional de Investigaciones Científicas y Técnicas (CONICET) PIP 11420080100201 to J. O. Ares. M. J. Rossi was a doctoral fellow from ANPCyT during 2009-2012. An anonymous reviewer, S. Thompson and C. Harman stimulated discussion on earlier versions of this paper.

Edited by: S. Thompson

\section{References}

Abraham, E., del Valle, H., Roig, F., Torres, L., Ares, J., Coronatp, F., and Godagnone, R.: Overview of the geography of the Monte desert of Argentina, J. Arid Environ., 73, 144-153, 2009.

Abrahams, A. D., Parsons, A. J., and Luk, S.: Field experiments on the resistance to overland flow on desert hillslopes, Erosion, Transport and Deposition Processes, in: Proceedings of the Jerusalem Workshop, March-April 1990, IAHS Publ. no. 189, Jerusalem, 1990.

Aguiar, M. R. and Sala, O. E.: Patch structure, dynamics and implications for the functioning of arid ecosystems, Trends Ecol. Evol., 14, 273-277, 1999.
Antoine, M., Chalon, C., Darboux, F., Javaux, M., and Bielders, C.: Estimating changes in effective values of surface detention, depression storage and friction factor at the interril scale, using a cheap and fast method to mold the soil surface microtopography, Catena, 91, 10-20, 2011.

Ares, J. O., Beskow, M., Bertiller, M. B., Rostagno, C. M., Irisarri, M., Anchorena, J., Deffosé, G., and Merino, C.: Structural and dynamic characteristic of overgrazed grassland of northern Patagonia, Argentina, in: Managed Grassland, Breymeyer, A., Elsevier Science, Amsterdam, 149-175, 1990.

Ares, J. O., del Valle, H. F., and Bisigato, A.: Detection of processrelated changes in plant patterns at extended spatial scales during early dryland desertification, Global Change Biol., 9, 16431659, 2003.

Bartley, R., Roth, C., Ludwig, J., McJannet, D., Liedloff, A., Corfield, J., Hawdon, A., and Abbott, B.: Runoff and erosion from Australia's tropical semi-arid rangelands: influence of ground cover for differing space and time scales, Hydrol. Process., 20, 3317-3333, 2006.

Biemelt, D., Schappa, A., Kleeberg, A., and Grünewald, U.: Overland flow, erosion, and related phosphorus and iron fluxes at plot scale: a case study from a non-vegetated lignite mining dump in Lusatia, Geoderma, 129, 4-18, 2005.

Borgogno, F., D’Odorico, P., Laio, F., and Ridolfi, L.: Mathematical models of vegetation pattern formation in ecohydrology, Rev. Geophys., 47, 1-36, 2009.

Bromley, J., Brouwer, J., Barker, A. P., Gaze, S. R., and Valentin, C.: The role of surface water redistribution in an area of patterned vegetation in a semi-arid environment, south-west Niger, J. Hydrol., 198, 1-29, 1997.

Cammeraat, L. H.: A review of two strongly contrasting geomorphological systems within the context of scale, Earth Surf. Proc. Land., 27, 1201-1222, 2002.

Carrera, A., Ares, J., Labraga, J., Thurner, S., and Bertiller, M.: Scenarios of Future Climate and Land-Management Effects on Carbon Stocks in Northern Patagonian Shrublands, Enviro. Manage., 40, 944-957, 2007.

Carrera, A. L., Bertiller, M. B., and Larreguy, C.: Leaf litterfall, fineroot production, and decomposition in shrublands with different canopy structure induced by grazing in the Patagonian Monte, Argentina, Plant Soil, 311, 39-50, 2008. 
Cerdá, A., Ibáñez, S., and Calvo, A.: Design and operation of a small and portable rainfall simulator for rugged terrain, Soil Technol., 11, 163-170, 1997.

Darboux, F., Davy, Ph., Gascuel-Odoux, C., and Huang, C.: Evolution of soil surface roughness and flowpath connectivity in overland flow experiments, Catena, 46, 125-139, 2001.

del Valle, H. F.: Patagonian soils: a regional synthesis, Ecología Austral, 8, 103-123, 1998.

Descroix, L., Viramontes, D., Estrada, J., Gonzalez Barrios, J. L., and Asseline, J.: Investigating the spatial and temporal boundaries of Hortonian and Hewlettian runoff in Northern Mexico, J. Hydrol., 346, 144-158, 2007.

Dingman, S. L.: Analytical derivation of at-a-station hydraulicgeometry relations, J. Hydrol., 334, 17-27, 2007.

Dunkerley, D. L.: Estimating the mean speed of laminar overland flow using dye-injection-Uncertainty on rough surfaces, Earth Surf. Proc. Land., 26, 363-374, 2001.

Dunkerley, D. L.: Infiltration rates and soil moisture in a groved mulga community near Alice Springs, arid central Australia: evidence for complex internal rainwater redistribution in a runoffrunon landscape, J. Arid Environ., 51, 199-219, 2002.

Dunkerley, D. L.: Determining friction coefficients for interrill flows. The significance of flow filaments for interrill flows, Earth Surf. Proc. Land., 28, 475-491, 2003.

Dunkerley, D. L.: Flow threads in surface run-off: implications for the assessment of flow properties and friction coefficients in soil erosion and hydraulics investigations, Earth Surf. Proc. Land., 29, 1011-1026, 2004.

Esteves, M., Faucher, X., Galle, S., and Vauclin, M.: Overland flow and infiltration modelling for small plots during unsteady rain: numerical results versus observed values, J. Hydrol., 228, 265282, 2000.

Ewen, J.: Hydrograph matching method for measuring model performance, J. Hydrol., 408, 178-187, 2011.

Gee, G. W. and Bauder, J. W.: Particle-size analysis, in: Methods of soil analysis, Part 1. Physical and mineralogical methods, 2nd Edn., edited by: Klute, A., Agronomy Monograph No. 9, ASA-SSSA, Madison, 383-411, 1986.

Giménez, R., Planchon, O., Silvera, N., and Govers, G.: Longitudinal velocity patterns and bed morphology interaction in a rill, Earth Surf. Proc. Land., 29, 105-114, 2004.

Govers, G., Takken, I., and Helming, K.: Soil roughness and overland flow, Agronomie, 20, 131-146, 2000.

Gowdish, L. and Muñoz-Cárpena, R.: An Improved Green-Ampt Infiltration and Redistribution Method for Uneven Multistorm Series, Vadose Zone J., 8, 470-479, 2009.

Green, W. H. and Ampt, G. A.: Studies on soil physics: 1. the flow of air and water through the soils, J. Agr. Sci., 4, 1-24, 1911.

Grierson, I. T. and Oades, J. M.: A rainfall simulator for field studies of run-off and soil erosion, J. Agr. Eng. Res., 22, 37-44, 1977.

Hansen, B.: Estimation of surface runoff and water-covered area during filling of surface micro relief depressions, Hydrol. Process., 14, 1235-1243, 2000.

Haylock, M. R., Peterson, T., Abreu de Sousa, J. R., Alves, L. M., Ambrizzi, T., Anunciação, Y. M. T., Baez, J., Barbosa de Brito, J. I., Barros, V. R., Berlato, M. A., Bidegain, M., Coronel, G., Corradi, V., Garcia, V. J., Grimm, A. M., Jaildo dos Anjos, R., Karoly, D., Marengo, J. A., Marino, M. B., Meira, P. R., Miranda, G. C., Molion, L., Moncunill, D. F., Nechet, D., Ontaneda, G.,
Quintana, J., Ramirez, E., Rebello, E., Rusticucci, M., Santos, J. L., Trebejo, I., and Vincent, L.: Trends in total and extreme South American rainfall in 1960-2000 and links with sea surface temperature, J. Climate, 19, 1490-1512, 2006.

Hessel, R., Jetten, V., and Guanghui, Z.: Estimating Manning's n for steep slopes, Catena, 54, 77-91, 2003.

Köhne, J. M., Köhne, S., and Simunek, J.: A review of model applications for structured soils: a) water flow and tracer transport, J. Contam. Hydrol., 104, 4-35, 2009.

Latron, J. and Gallart, F.: Seasonal dynamics of runoff-contributing areas in a small Mediterranean research catchment (Vallcebre, Eastern Pyrenees), J. Hydrol., 335, 194-206, 2007.

Legout, C., Darboux, F., Nédélec, Y., Hauet, A., Esteves, M., Renaux, B., Denis, H., and Cordier, S.: High spatial resolution mapping of surface velocities and depths for shallow overland flow, Earth Surf. Proc. Land., 37, 984-993, 2012.

León, R. J. C., Bran, D., Collantes, M., Paruelo, J. M., and Soriano, A.: Grandes unidades de vegetación de la Patagonia extraandina, Ecología Austral, 8, 125-144, 1998.

Li, G.: Preliminary study of the interference of surface objects and rainfall in overland flow resistance, Catena, 78, 154-158, 2009.

Li, X., Contreras, S., Solé-Benet, A., Cantón, Y., Domingo, F., Lázaro, R., Lin, H., Van Wesemael, B., and Puigdefábregas, J.: Controls of infiltration-runoff processes in Mediterranean karst rangelands in SE Spain, Catena, 86, 98-109, 2011.

Lipsius, K. and Mooney, S. J.: Using image analysis of tracer staining to examine the infiltration patterns in a water repellent contaminated sandy soil, Geoderma, 136, 865-875, 2006.

Mao, L. L., Lei, T. W., Li, X., Liu, H., Huang, X. F., and Zhang, Y. N.: A linear source method for soil infiltrability measurement and model representations, J. Hydrol., 353, 49-58, 2008.

Mares, M. A., Morello, J., and Goldstein, G.: Semi-arid shrublands of the world, in: Hot deserts and arid shrublands, Ecosystems of the world, chapter 10, edited by: Evenari, M., Noy-Meir, I., and Goodall, D., Elsevier, Amsterdam, The Netherlands, 203-237, 1985.

Mengistu, B., Defersha, A., and Melesse, M.: Field-scale investigation of the effect of land use on sediment yield and runoff using runoff plot data and models in the Mara River basin, Kenya, Catena, 89, 54-64, 2012.

Morello, J. H.: Perfil Ecológico de Sud América, Instituto de Cooperación Iberoamericana, Madrid, 93 pp., 1984.

Mualem, Y.: A new model for predicting the hydraulic conductivity of unsaturated porous media, Water Resour. Res., 12, 593-622, 1976.

Mügler, C., Planchon, O., Patin, J., Weill, S., Silvera, N., Richard, P., and Mouche, E.: Comparison of roughness models to simulate overland flow and tracer transport experiments under simulated rainfall at plot scale, J. Hydrol., 402, 25-40, 2011.

Nash, J. E. and Sutcliffe, J. V.: River flow forecasting through conceptual models, 1, a discussion of principles, J. Hydrol., 10, 282290, 1970.

Nofziger, D. L. and Wu, J.: CHEMFLO-2000, Interactive Software for Simulating Water and Chemical Movement in Unsaturated Soils, Department of Plant and Soil Sciences Oklahoma State University Stillwater, Oklahoma, 2003. 
Parenti, L. R. and Ebach, M. C.: Comparative Biogeography, Univ. of California Press, Princeton, 312 pp., 2009.

Parsons, A. J. and Wainwright, J.: Depth distribution of interrill overland flow and the formation of rills, Hydrol. Process., 20, 1511-1523, 2006.

Parsons, A. J., Abrahams, A. D., and Wainwright, J.: On determining resistance to interrill overland flow, Water Resour. Res., 30, 3515-3521, 1994.

Planchon, O. and Darboux, F.: A fast, simple and versatile algorithm to fill the depressions of digital elevation models, Catena, 46, 159-176, 2002.

Prohaska, F.: The climate of Argentina, Paraguay and Uruguay, in: Climates of Central and South America, Chapter 2, edited by: Schverdtfeger, W., Elsevier, Amsterdam, 532 pp., 1976.

Radcliffe, D. R. and Simunek, J.: Soil Physics with HYDRUS: Modeling and Applications, CRC Press, New York, 2010.

Reaney, S. M.: The use of agent based modelling techniques in hydrology: determining the spatial and temporal origin of channel flow in semi-arid catchments, Earth Surf. Proc. Land., 33, 317327, 2008.

Rosewell, C. J.: Rainfall kinetic energy in Eastern Australia, J. Clim. Appl. Meteorol., 25, 1695-1701, 1986.

Rossi, M. J. and Ares, J. O.: Close range stereo-photogrammetry and video imagery analyses in soil eco-hydrology modelling, Photogramm. Record, 27, 111-126, 2012.

Schaap, M. G. and Leij, F. J.: Database Related Accuracy and Uncertainty of Pedotransfer Functions, Soil Sci., 163, 765-779, 1998.

Schröder, A.: WEPP, EUROSEM, E-2D results of application at the plot scale, in: Soil Erosion-Application of Physically Based Models, edited by: Schmidt, J., Springer Verlag, Berlin, Heidelberg, New York, 199-250, 2000.
Smith, M. W., Cox, N. J., and Bracken, L. J.: Applying flow resistance equations to overland flows, Prog. Phys. Geogr., 31, 363387, 2007.

Smith, M. W., Cox, N. J., and Bracken, L. J. Modeling depth distribution of overland flows, Geomorphology, 125, 402-413, 2011.

Soriano, A.: La vegetación del Chubut, Revista Argentina de Agronomía, 17, 30-66, 1950.

Tarboton, D. G. and Ames, D. P.: Advances in the mapping of flow networks from digital elevation data, World Water and Environmental Resources Congress, 20-24 May, ASCE, Orlando, Florida, 2001.

Tatard, L., Planchon, O., Wainwright, G., Nord, J., Favis-Mortlock, D., Silvera, N., Ribolzi, O., Esteves, M., and Huang C.H.: Measurement and modelling of high-resolution flow-velocity data under simulated rainfall on a low-slope sandy soil, J. Hydrol., 348, $1-12,2008$.

Thompson, S., Katul, G., Konings, A., and Ridolfi, L.: Unsteady overland flow on flat surfaces induced by spatial permeability contrasts, Adv. Water Resour., 34, 1049-1058, 2011.

van Genuchten, M. Th.: A closed form equation for predicting the hydraulic conductivity of unsaturated soils, Soil Sci. Soc. Am. J., 44, 892-898, 1980.

van Schaik, N. L.: Spatial variability of infiltration patterns related to site characteristics in a semi-arid watershed, Catena, 78, 3647, 2009.

Wang, J., Yang, H., Li, L., Gourley, J., Sadiq, K., Yilmaz, K., Adler, R., Policelli, F., Habib, S., Irwin, D., Limaye, A., Korme, T., and Okello, L.: The coupled routing and excess storage distributed hydrological model, Hydrolog. Sci. J., 56, 84-98, 2011.

Weill, S., Mazzia, A., Putti, M., and Paniconi, C.: Coupling water flow and solute transport into a physically-based surfacesubsurface hydrological model, Adv. Water Resour., 34, 128136, 2011. 